\title{
Natural regeneration responses to thinning and burning treatments in ponderosa pine forests and implications for restoration
}

\author{
Tzeidle N. Wasserman ${ }^{1} \cdot$ Amy E. M. Waltz ${ }^{1}$. \\ John Paul Roccaforte ${ }^{1} \cdot$ Judith D. Springer $^{1}$. \\ Joseph E. Crouse ${ }^{1}$
}

Received: 28 June 2021 / Accepted: 6 September 2021 / Published online: 19 October 2021

(C) The Author(s) 2021

\begin{abstract}
Understanding naturally occurring pine regeneration dynamics in response to thinning and burning treatments is necessary not only to measure the longevity of the restoration or fuels treatment, but also to assess how well regeneration meets forest sustainability guidelines and whether natural regeneration is sufficient for maintaining a sustainable forest structure and composition. A synthesis review was carried out on the effects of mechanical thinning and prescribed burn treatments on natural pine regeneration response in frequent-fire ponderosa pine forests across the western United States. The focus was on site-specific variability in pine regeneration dynamics, temporal trends in regeneration presence and abundance, and response to treatment as described in the current literature using 29 studies that met our evidence-based review protocols. Data showed that the effects of thinning and burning treatments on regeneration depended on time since treatment. Mechanical thinning, prescribed burning, and thinning plus burn treatments all increased seedling density, but there was high variability among sites and studies. There were mixed results in the short-term $(<10$ years $)$ with both increasing and decreasing regeneration, and a general increase in regeneration $11-20$ years post-treatment. Some long-term studies
\end{abstract}

Project funding: Funding came fromwithin the Ecological Restoration Institute

The online version is available at http://www.springerlink.com.

Corresponding editor: Yu Lei.

Tzeidle N. Wasserman

Tzeidle.Wasserman@nau.edu

1 Ecological Restoration Institute, Northern Arizona University, P.O. Box 15017, Flagstaff, AZ 86011-5017, USA
( $>20$ years) concluded that stands can return to pre-treatment densities in terms of total trees per hectare and forest floor duff levels when there are no maintenance treatments applied. Several studies showed the average ponderosa pine seedling presence, survival and growth found in today's forests to be at a high density; this combined with missed fire cycles could contribute to future fire risk and reduce the efficacy of maintaining fuel reduction goals.

Keywords Regeneration - Ponderosa pine $\cdot$ Frequentfire $\cdot$ Treatments $\cdot$ Thinning $\cdot$ Burning

\section{Introduction}

Forest management in western frequent-fire forests is driven by the need for ecological restoration and hazardous fuel treatments to reduce the risk of uncharacteristic, high-severity fire. Today's ponderosa (Pinus ponderosa Douglas ex P. Lawson \& C. Lawson) forests are currently five to 20 times denser than estimates of historic forests, and often burn with high-severity from both natural- and human-caused fire starts (Covington and Moore 1994; Allen et al. 2002; Graham and Jain 2005; Hagmann et al. 2013; Huago et al. 2019). In the western United States, the majority of these forest types are on federally owned land, with the largest portion managed by the United States Forest Service (USFS). Some of the largest barriers to restoring these forests and reducing wildfire risk is the cost of fuel treatments, increased numbers of people moving in the wildland urban interface, social acceptance of thinning and burning, and smoke tolerance from managed wildfire and prescribed burning (Schoennagel et al. 2017; Merschel et al. 2021). Current management priorities in frequentfire forests include reducing tree density, reducing fuels, 
decreasing fire hazards and severity, enhancing forest ecosystem components, and improving biological diversity via mechanical thinning and prescribed burning treatments (Healthy Forests Restoration Act of 2003 [P.L. 108-148]).

Understanding naturally occurring ponderosa pine regeneration dynamics in response to thinning and burning is necessary, not only to measure the longevity of the restoration or fuels treatment, but to assess how well regeneration meets forest sustainability guidelines under the National Forest Management Act (1976). Frequentfire forests have complex dynamics that have evolved over millennia (Swetnam 1993; Stephens et al. 2003). Pre EuroAmerican settlement, frequent, low-severity surface fires dominated the disturbance regime and maintained relatively open, multi-aged and diverse forested stands (Agee 1993; Covington and Moore 1994; Keeley and Zedler 1998; Stephens et al. 2003, 2015; Hagmann et al. 2013). Changes in historical disturbance regimes, in combination with climatic change and more frequent occurrence of large-scale high severity fire have led to additional barriers and challenges to natural regeneration. Warmer and drier conditions are predicted across the western U.S. (Seager et al. 2007; Gutzler and Robbins 2011; IPCC 2013, 2018), and changes in vegetation composition in forests are predicted in the near future (Allen et al. 2010; Breshears et al. 2005; Hanberry 2014). Changes in seasonal precipitation, soil conditions, and soil water availability affect regeneration establishment and persistence (Petrie et al. 2016; Dey et al. 2019). Prolonged drought conditions, warmer temperatures, and reduced precipitation may impact natural pine regeneration and persistence, however the specific environmental conditions necessary for successful regeneration in any given region vary (Petrie et al. 2016).

Successful ponderosa pine regeneration is episodic in nature, constrained by climate, and sensitive to specifically timed precipitation and temperature patterns (Brown and $\mathrm{Wu}$ 2005; League and Veblen 2006; Savage et al. 2013; Flathers et al. 2016). Successful regeneration rates are further regulated by soil moisture, predation of seeds/cones, seedbed conditions, and competition with grasses and understory vegetation (Pearson 1950; Meagher 1950; Heidmann 2008; Puhlick et al. 2012; Flathers et al. 2016; Petrie et al. 2016). Historically, regeneration was naturally limited by frequent, low-severity fires (Brown and Wu 2005; Savage et al. 2013). In recent decades, fire regimes in the western U.S. have changed in response to warming temperatures and drought, and fire seasons have become longer, wildfires are more frequent and larger, and area burned is increasing annually (Westerling et al. 2011; Moritz et al. 2012; Dennison et al. 2014; Jolly et al. 2015; Abatzoglou and Williams 2016; Westerling 2016). In addition, patches burned at high severity often have limited adjacent seed sources for regeneration, and forests may experience an ecosystem conversion to shrubs or grasses post-wildfire (Owen et al. 2017; Korb et al. 2019).

Studies on the relationship between ponderosa pine cone and seed production with stand structure and abiotic conditions demonstrate that thinning can increase individual tree reproductive output, and greater cone production and cone mass was observed at lower tree densities (Flathers et al. 2016). Seedling mortality was high the first two years (Stein and Kimberling 2003; Sheppard et al. 2006; Keyes et al. 2007) but slowed around seven years of age (Sheppard et al. 2006). Ponderosa pine regeneration was also highly influenced by parent material and soil type, with sedimentary soils most often having more water availability and soil moisture than basalt soils (Heidmann 1988; Puhlick et al. 2012), and often had higher densities (Ffolliott and Baker 1977; Heidmann 1988; Goodwin 2004) and grew faster on sedimentary soils.

Abundant ponderosa pine seed crops can lead to prolific regeneration and growth, often exceeding thousands of stems per hectare (Shepperd and Battaglia 2002; Battaglia 2007; Flathers et al. 2016). Historically, frequent, low-severity fires kept seedling density low and limited survival through time to the densities observed in historic reconstructions (Brown and Wu 2005; Savage et al. 2013). However, the absence of frequent fires and intact fire regimes, combined with good seed years, has led to seedling and sapling densities well above those estimated historically in many areas, and have contributed to the high fuel loadings seen in contemporary forests. This excess regeneration can increase surface fuel accumulation and create ladder fuels, thus increasing crown fire hazard (Battaglia et al. 2009).

Maintaining fuel treatment effectiveness to reduce wildfire hazard is a management priority, as costs of mechanical treatments are high and the pace and scale of treatment implementation can be challenging. Treatments generally consist of the removal of trees via mechanical thinning and prescribed fire, or use of prescribed fire alone. These treatments are meant to reduce surface fuel accumulations and high severity wildfire behavior (Agee and Skinner 2005). Regeneration dynamics and the continued growth of seedlings and saplings affect fire hazard and stand density and are important factors to consider when evaluating treatment effectiveness and longevity.

Understanding regeneration dynamics in frequent-fire forests and expected needs in a climate-altered future are integral for managing for resilience. In this review, we qualitatively synthesized publications that examined natural pine regeneration following restoration or fuel reduction treatments in frequent-fire ponderosa pine forests. The directional and temporal responses of natural pine regeneration to thinning and burning treatments were examined, and how time since treatment had influenced the presence/ absence and abundance of ponderosa pine regeneration. The 
results of our synthesis are discussed in the context of the contemporary challenges and climate change, management recommendations are made in consideration of maintaining treatment effectiveness and reducing wildfire risk, and research gaps are identified. To our knowledge, there has not been an effort to synthesize these publications for scientists and land managers, and this synthesis will address if natural pine regeneration post-treatment is sufficient to meet forest sustainability guidelines for federally managed lands.

\section{Materials and methods}

This synthesis was carried out using evidence-based review protocols (Pullin and Stewart 2006; Lortie 2014) to find the relevant body of literature that exists on this subject area. Search strings and multiple relevant databases were used to identify relevant publications. The search strings included: ponderosa pine OR pinus ponderosa, AND regeneration OR seedlings OR saplings, AND treatment, AND thin OR burn OR restoration OR fuels reduction. Five independent online science-based search engines were examined, including CAB Abstracts, ProQuest, BIOSIS, and Web of Science, Google Scholar, and the literature cited of relevant publications prior to March 2021. The potentially relevant publications were screened to eliminate those that did not meet our inclusion criteria (Table 1), and the remaining papers were searched to determine if all criteria were met. Papers were removed that were conference papers or conference abstracts, as the rigor and quality of information was inconsistent. Modeling studies were removed that did not present empirical field data as a response variable for ponderosa pine regeneration. Papers were excluded that focused on facilitated regeneration, including seeding, sowing, planting, or any other form of regeneration manipulation. Reviewers did not assess papers that they authored. A final set of papers that met the criteria were summarized. Because this was strictly a synthesis review and not a meta-analysis, we did not report statistical effect size. The quality of each paper was assessed based on whether the paper was peer reviewed or grey literature (e.g., theses, agency reports, other). Publications produced by the initial search were supplemented with additional publications that were determined to be missing based on our personal knowledge of the subject.

Qualitative data on treatments and regeneration responses were compared across treatments. Regeneration was defined as individuals from new germinants to seedlings less than diameter breast height (dbh, $1.37 \mathrm{~m}$ above ground) and 0.25 to $10 \mathrm{~cm} \mathrm{dbh}$. Treatment type and time since treatment were used as data extraction variables. Time since treatment was binned into four categories: very short-term ( $\leq 1$ year), short-term $(2-10$ years), moderate-term $(11-20$ years) and long-term ( $>20$ years). Regeneration response to treatments was assessed as a categorical (increase or decrease) change in presence or absence, density (number per hectare), and abundance. Regeneration responses to either control plots or untreated areas, and among treatment types, were compared. These studies were summarized by study area, dominant forest type, elevation, annual precipitation, and parent material (Table 2).

\section{Results}

\section{Literature review}

The initial review of titles and abstracts from our search strings produced 109 papers that addressed ponderosa pine, natural regeneration and treatments (thinning, burning, thinning plus burning). After assessing these papers to meet our criteria, a final set of 29 papers addressed natural regeneration responses following fuel reduction, restoration, and fire risk reduction treatments in ponderosa pine ecosystems (Table 2). Of these final set of papers, the majority (26) were
Table 1 Criteria for publications used in this review of changes in regeneration presence, absence, and abundance after thinning and burning treatments

\begin{tabular}{ll}
\hline Criteria & Description \\
\hline Species & Ponderosa pine (Pinus ponderosa P. Lawson \& C. Lawson) \\
Range & Western United States \\
Population & Publication analyzed naturally occurring regeneration post- treatment \\
& Not facilitated regeneration (no planting, seeding, or sowing) \\
& Ponderosa pine one species in a multi-species group \\
& Ponderosa pine was the dominant species in a multi-species group \\
& Publication analyzed treatment type (thinning, burning, thin- \\
Comparator & ning + burning) and time since treatment as an explanatory variable \\
& of post-treatment regeneration \\
Outcomes & Publication analyzed regeneration density, presence or absence as a \\
& measure of post-treatment regeneration abundance as the response \\
Oariable & Publications were refereed journal, grey literature, government reports \\
\end{tabular}


Table 2 Studies included in this systematic review and their geographic location, forest type, elevation, annual precipitation, parent material, treatment type (thin, burn, thin + burn), and time since treatment

\begin{tabular}{|c|c|c|c|c|c|c|c|c|}
\hline Study \# & Authors & Study location & Forest type & Elevation (m) & $\begin{array}{l}\text { Annual } \\
\text { precipitation } \\
(\mathrm{cm})\end{array}$ & Parent material & Treatment type & $\begin{array}{l}\text { Time since } \\
\text { treatment }\end{array}$ \\
\hline 1 & $\begin{array}{l}\text { Abella and } \\
\text { Covington } \\
2007\end{array}$ & $\begin{array}{l}\text { Northern Ari- } \\
\text { zona }\end{array}$ & P. ponderosa & 2300 & 57 & Basalt & Thin + Burn & $5-6$ yrs \\
\hline 2 & $\begin{array}{l}\text { Bailey and } \\
\text { Covington } \\
2002\end{array}$ & $\begin{array}{l}\text { Northern Ari- } \\
\text { zona }\end{array}$ & P. ponderosa & 2240 & 57 & Basalt & Thin + Burn & $5-6$ yrs \\
\hline 3 & $\begin{array}{l}\text { Battaglia et al. } \\
2008\end{array}$ & $\begin{array}{l}\text { Black Hills, } \\
\text { South Dakota }\end{array}$ & P. ponderosa & $1000-2207$ & $41-74$ & Granite, Schist & Burn & $1 \mathrm{yr}$ \\
\hline 4 & $\begin{array}{l}\text { Battaglia et al. } \\
2009\end{array}$ & $\begin{array}{l}\text { Black Hills, } \\
\text { South Dakota }\end{array}$ & P. Ponderosa & $1000-2200$ & $41-74$ & Granite, Schist & Burn & 8 months \\
\hline 5 & $\begin{array}{l}\text { Bigelow et al. } \\
2011\end{array}$ & $\begin{array}{l}\text { Sierra Nevada, } \\
\text { California }\end{array}$ & $\begin{array}{l}\text { P. ponderosa, } \\
\text { P. jeffreyi }\end{array}$ & $1200-1650$ & $38-200$ & $\begin{array}{l}\text { Granite, Slate, } \\
\text { Sandstone, } \\
\text { Chert }\end{array}$ & Thin + Burn & 4 yrs \\
\hline 6 & $\begin{array}{l}\text { Briggs et al. } \\
2017\end{array}$ & $\begin{array}{l}\text { Front Range, } \\
\text { Colorado }\end{array}$ & P. ponderosa & $1960-2740$ & 55 & Granite, Gneiss & Thin & $1-2$ yrs \\
\hline 7 & $\begin{array}{l}\text { Clyatt et al. } \\
2017\end{array}$ & $\begin{array}{l}\text { Southwestern } \\
\text { Montana }\end{array}$ & $\begin{array}{l}\text { P. ponderosa } P \text {. } \\
\text { menziesii }\end{array}$ & $1300-1500$ & 40 & Granite & $\begin{array}{l}\text { Thin, } \\
\text { Thin + Burn }\end{array}$ & $23 \mathrm{yrs}$ \\
\hline 8 & Cueno 2011 & $\begin{array}{l}\text { Black Hills, } \\
\text { South Dakota }\end{array}$ & P. ponderosa & $1006-2164$ & $41-74$ & $\begin{array}{l}\text { Mica schist, } \\
\text { Metamor- } \\
\text { phosed } \\
\text { quartzite and } \\
\text { pelite }\end{array}$ & $\begin{array}{l}\text { Thin, } \\
\text { Thin + Chip, } \\
\text { Thin + Burn }\end{array}$ & $2 \mathrm{yrs}$ \\
\hline 9 & $\begin{array}{l}\text { Fajardo et al. } \\
2007\end{array}$ & $\begin{array}{l}\text { Southwestern } \\
\text { Montana }\end{array}$ & $\begin{array}{l}\text { P. ponderosa } P \text {. } \\
\text { menziesii }\end{array}$ & 1500 & 40 & Granite & $\begin{array}{l}\text { Thin, } \\
\text { Thin + Burn }\end{array}$ & $10 \mathrm{yrs}$ \\
\hline 10 & $\begin{array}{l}\text { Ffolliott and } \\
\text { Guertin } 1990\end{array}$ & $\begin{array}{l}\text { Northern Ari- } \\
\text { zona }\end{array}$ & P. ponderosa & 2000 & 64 & Volcanic & Burn & $\begin{array}{l}1,2,11, \& 24 \\
\mathrm{yrs}\end{array}$ \\
\hline 11 & $\begin{array}{l}\text { Ffolliott et al. } \\
2009\end{array}$ & $\begin{array}{l}\text { Northern Ari- } \\
\text { zona }\end{array}$ & P. ponderosa & 2000 & 64 & Volcanic & Burn & $1 \mathrm{yr}, 43 \mathrm{yrs}$ \\
\hline 12 & $\begin{array}{l}\text { Fiedler et al. } \\
2010\end{array}$ & $\begin{array}{l}\text { Western Mon- } \\
\text { tana }\end{array}$ & $\begin{array}{l}\text { P. ponderosa } P \text {. } \\
\text { menziesii }\end{array}$ & $1263-1388$ & 50 & Granite & $\begin{array}{l}\text { Thin, Burn, } \\
\text { Thin + Burn }\end{array}$ & $3 \mathrm{yrs}$ \\
\hline 13 & $\begin{array}{l}\text { Flathers et al. } \\
2016\end{array}$ & $\begin{array}{l}\text { Northern Ari- } \\
\text { zona }\end{array}$ & P. ponderosa & 2266 & 56 & Basalt & Thin & $12 \mathrm{yrs}$ \\
\hline 14 & $\begin{array}{l}\text { Francis et al. } \\
2018\end{array}$ & $\begin{array}{l}\text { North-central } \\
\text { Colorado }\end{array}$ & $\begin{array}{l}\text { P. ponderosa } P \text {. } \\
\text { menziesii }\end{array}$ & $2350-2650$ & $40-55$ & Alluvium & $\begin{array}{l}\text { Thin, } \\
\text { Thin + Burn }\end{array}$ & $3,4,8,12 \mathrm{yrs}$ \\
\hline 15 & Fulé et al. 2002 & $\begin{array}{l}\text { Northern Ari- } \\
\text { zona }\end{array}$ & $\begin{array}{l}\text { P. ponderosa, } \\
\text { Q. gamebelli }\end{array}$ & 2290 & 36.8 & Sandstone & $\begin{array}{l}\text { Thin, Burn, } \\
\text { Thin + Burn }\end{array}$ & $1 \mathrm{yr}$ \\
\hline 16 & Fulé et al. 2007 & $\begin{array}{l}\text { Northern Ari- } \\
\text { zona }\end{array}$ & $\begin{array}{l}\text { P. ponderosa } \\
\text { Q. gamebelli }\end{array}$ & $2000-2250$ & 43 & Basalt & Thin + Burn & $1 \mathrm{yr}, 5 \mathrm{yrs}$ \\
\hline 17 & $\begin{array}{l}\text { Gaines et al. } \\
1958\end{array}$ & $\begin{array}{l}\text { East-central } \\
\text { Arizona }\end{array}$ & P. ponderosa & 2255 & 49 & Basalt & Burn & 2 months, 2 yrs \\
\hline 18 & $\begin{array}{c}\text { Kalabokidis } \\
\text { and Waki- } \\
\text { moto } 1992\end{array}$ & $\begin{array}{l}\text { Western Mon- } \\
\text { tana }\end{array}$ & $\begin{array}{l}\text { P. ponderosa } P \text {. } \\
\text { menziesii }\end{array}$ & 1250 & 45.5 & Volcanic & Thin + Burn & $1 \mathrm{yr}$ \\
\hline 19 & $\begin{array}{l}\text { Metlen and } \\
\text { Fiedler } 2006\end{array}$ & $\begin{array}{l}\text { Western Mon- } \\
\text { tana }\end{array}$ & $\begin{array}{l}\text { P. ponderosa } P \text {. } \\
\text { menzeseii }\end{array}$ & $1250-1350$ & 55 & Volcanic & $\begin{array}{l}\text { Thin, } \\
\text { Thin + Burn, } \\
\text { Burn }\end{array}$ & $1,2,3 \mathrm{yrs}$ \\
\hline 20 & $\begin{array}{l}\text { Moghaddas } \\
\text { et al. } 2008\end{array}$ & $\begin{array}{l}\text { Sierra Nevada, } \\
\text { California }\end{array}$ & mixed conifer & $1100-1410$ & 160 & $\begin{array}{l}\text { Granite, Grano- } \\
\text { diorite }\end{array}$ & $\begin{array}{l}\text { Thin, burn, } \\
\text { Thin + burn }\end{array}$ & $4 \mathrm{yrs}$ \\
\hline 21 & $\begin{array}{l}\text { Roccaforte } \\
\text { et al. } 2010\end{array}$ & $\begin{array}{c}\text { Northwest } \\
\text { Arizona }\end{array}$ & $\begin{array}{l}\text { P. ponderosa } \\
\text { Q. gambelii }\end{array}$ & $2000-2250$ & $31-39$ & Basalt & Thin + Burn & $6-7$ yrs \\
\hline 22 & $\begin{array}{l}\text { Roccaforte } \\
\text { et al. } 2015\end{array}$ & $\begin{array}{l}\text { East-central } \\
\text { Arizona }\end{array}$ & P. ponderosa & $2340-2580$ & 49.4 & Volcanic & $\begin{array}{l}\text { Burn, } \\
\text { Thin + Burn }\end{array}$ & $1 \mathrm{yr}, 5 \mathrm{yrs}$ \\
\hline
\end{tabular}


Table 2 (continued)

\begin{tabular}{|c|c|c|c|c|c|c|c|c|}
\hline Study \# & Authors & Study location & Forest type & Elevation (m) & $\begin{array}{l}\text { Annual } \\
\text { precipitation } \\
(\mathrm{cm})\end{array}$ & Parent material & Treatment type & $\begin{array}{l}\text { Time since } \\
\text { treatment }\end{array}$ \\
\hline 23 & $\begin{array}{c}\text { Sackett, S.S. } \\
1984\end{array}$ & $\begin{array}{l}\text { Northern Ari- } \\
\text { zona }\end{array}$ & P. ponderosa & 2270 & 56 & Volcanic & Burn & 4 yrs \\
\hline 24 & $\begin{array}{l}\text { Stevens et al. } \\
2014\end{array}$ & $\begin{array}{l}\text { Eastern and } \\
\text { southern } \\
\text { California }\end{array}$ & P. ponderosa & $2000-3800$ & $40-180$ & $\begin{array}{l}\text { Granite, Slate, } \\
\text { Sandstone, } \\
\text { Chert }\end{array}$ & Thin + Burn & $2-10 \mathrm{yrs}$ \\
\hline 25 & $\begin{array}{l}\text { Stoddard et al. } \\
2015\end{array}$ & $\begin{array}{l}\text { Southwestern } \\
\text { Colorado }\end{array}$ & mixed conifer & $2438-2743$ & 55 & $\begin{array}{c}\text { Granite, Sand- } \\
\text { stone, Shale, } \\
\text { Limestone }\end{array}$ & $\begin{array}{l}\text { Burn, } \\
\text { Thin + Burn }\end{array}$ & $5 \mathrm{yrs}$ \\
\hline 26 & $\begin{array}{l}\text { Thomas and } \\
\text { Waring } 2015\end{array}$ & $\begin{array}{l}\text { Northeastern } \\
\text { New Mexico }\end{array}$ & P. ponderosa & $2350-2530$ & 41.4 & $\begin{array}{l}\text { Sandstone and } \\
\text { Shale }\end{array}$ & Thin + Burn & $20,25 \mathrm{yrs}$ \\
\hline 27 & $\begin{array}{l}\text { Waltz et al. } \\
2003\end{array}$ & $\begin{array}{l}\text { Northwestern } \\
\text { Arizona }\end{array}$ & $\begin{array}{l}\text { P. ponderosa } \\
\text { Q. gambelii }\end{array}$ & $1675-2620$ & $40-45$ & $\begin{array}{l}\text { Basalt and lava/ } \\
\text { Cinder }\end{array}$ & Thin + Burn & $1 \mathrm{yr}$ \\
\hline 28 & $\begin{array}{r}\text { Westlind and } \\
\text { Kerns } 2017\end{array}$ & $\begin{array}{l}\text { East-central } \\
\text { Oregon }\end{array}$ & P. ponderosa & $1570-1740$ & 46 & Volcanic & Thin + Burn & $5,15 \mathrm{yrs}$ \\
\hline 29 & $\begin{array}{l}\text { Wolk and } \\
\text { Rocca } 2009\end{array}$ & $\begin{array}{l}\text { Northern Colo- } \\
\text { rado }\end{array}$ & P. ponderosa & 1921-2069 & 49 & $\begin{array}{c}\text { Granite, Sand- } \\
\text { stone, Shale, } \\
\text { Limestone }\end{array}$ & $\begin{array}{l}\text { Thin, } \\
\text { Thin + Chip, } \\
\text { Thin + Burn }\end{array}$ & $5 \mathrm{yrs}$ \\
\hline
\end{tabular}

in refereed journals and three were considered grey literature. Studies were located in Arizona (12), Colorado (4), Montana (5), New Mexico (1), Oregon (1), South Dakota (3), and California (3) (Tables 2 and 3, Fig. 1). Treatment type varied by study and a single study could focus on multiple treatments (Table 2). Treatment goals varied by study and included forest restoration, fuel reduction, fire hazard reduction and research. The most pertinent studies were published relatively recently, with 25 of the 29 published after 2000.

Half of the reviewed studies (15) reported both preand post-treatment effects on regeneration. Other studies included control data for overstory measurements pre- and post-treatment, but no control data on regeneration. The most commonly reported regeneration responses were presence/absence, stem density (number per hectare), survival, and growth (height and diameter). Because regeneration response metrics varied among studies and density responses were variable, regeneration responses were characterized as either increasing or decreasing following treatment compared to control plots, pre-treatment information, untreated areas, or plot-level monitoring.

\section{Summary of regeneration responses to thinning and burning treatments}

There were varying time since treatment effects on the regeneration response. Thin, burn, and thin plus burn treatments displayed both increasing and decreasing trends in regeneration responses compared to pre-treatment or control plots, and through time. Studies with repeated measurements showed a time since treatment effect on the regeneration response.

In the short-term ( $\leq 1$ year) thin and thin + burn treatments both increased and decreased regeneration density within one-year post-treatment. Burn-only treatments also displayed mixed effects $\leq 1$ year post-burn where low- to moderate-severity fire both increased and decreased the presence and density of regeneration compared to pre-treatment levels (Gaines et al. 1958; Battaglia et al. 2008; Roccaforte

Table 3 A total of 29 studies by treatment type, time since treatment, and regeneration response

\begin{tabular}{|c|c|c|c|c|c|c|c|c|}
\hline \multirow[t]{3}{*}{ Treatment } & \multicolumn{8}{|c|}{ Time since treatment- Regen response } \\
\hline & $<1-1 \mathrm{yr}$ & $<1-1 \mathrm{yr}$ & $2-10 \mathrm{yrs}$ & $2-10 \mathrm{yrs}$ & $10-20 \mathrm{yrs}$ & $10-20 \mathrm{yrs}$ & $20+y r s$ & $20+y r s$ \\
\hline & Increase & Decrease & Increase & Decrease & Increase & Decrease & Increase & Decrease \\
\hline Thin Only & 14 & 15,19 & $8,14,20,22,29$ & 12,19 & $9,13,14$ & & & 7 \\
\hline Burn Only & $3,10,17$ & $4,15,19,22$ & $20,22,23$ & $12,17,19,25$ & 10 & & & $7,10,11$ \\
\hline Thin + Burn & $14,18,27$ & $6,15,16,18,19,22$ & $5,8,14,20,22,29$ & $\begin{array}{r}1,2,6,12,16 \\
19,21,14,25\end{array}$ & $9,14,26,28$ & 5,28 & 7 & 26 \\
\hline
\end{tabular}

Numbers correspond to study numbers in Table 2. Some studies had multiple re-measurements and treatment types and appear multiple times 
Fig. 1 Geographical distribution of ponderosa pine, review studies, and locations included in this review; location numbers correspond to Tables 2 and 3

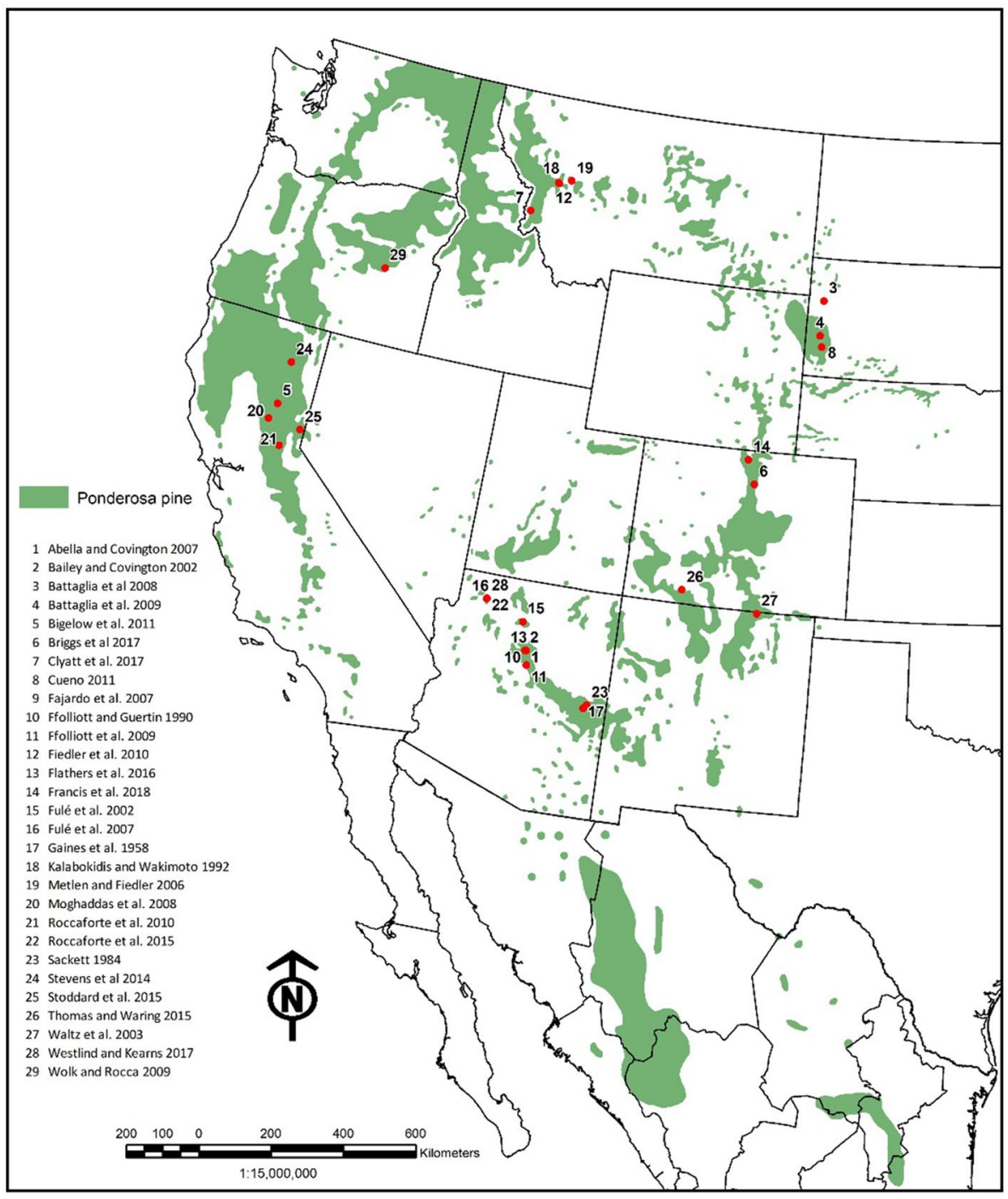

et al. 2015) (Table 3). Mixed responses were observed at shorter times since treatment ranges $(2-10$ years $)$. Both increases and decreases in the presence and density of regeneration were observed following all three treatments (thin-only, burn-only, thin plus burn) (Table 3) and exhibited mixed patterns. Some studies such as Bigelow et al. 2011, further delineated treatments into thinning intensities. In this category, Bigelow et al. 2011 found increased regeneration following medium intensity thinning, but decreased regeneration in the most intense thinning treatment. Our sample depth did not allow for the examination of different thinning intensity impacts on regeneration. In the moderate-term (11-20 years), there was a pattern of increased regeneration and density, especially in thin-only and thin + burn treatments (Ffolliot and Guertin 1990; Fajardo et al. 2007; Flathers et al. 2016; Francis et al. 2018; Thomas and Waring 2015). Increased regeneration followed low- to moderateseverity burn-only treatments (Ffolliott and Guertin 1990). Studies greater than 20 years showed an overall decrease in regeneration post-treatment across all treatment types (Ffolliot and Guertin 1990; Ffolliott et al. 2009; Thomas and Waring 2015; Clyatt et al. 2017).

\section{Discussion}

Thinning and burning treatments had variable effects on natural regeneration in frequent-fire pine forests and strongly depend on the time since treatment. This showed some consistent trends, most often as an increase in regeneration $11-20$ years following treatments. Studies displayed both increases and decreases in regeneration immediately following treatment ( $\leq 1$ year) across all treatment types due site variability and treatment goals. Where decreases in regeneration density was observed, it suggested that this was due to initial site disturbance by heavy equipment and removal of overstory trees (Harrod et al. 2009; Bigelow et al. 2011). Increases in regeneration 
after burn-only treatments were due to exposure of mineral soil and increased availability of nutrients and light. Low- to moderate-intensity burning increases soil nutrient availability (nitrogen) and provides favorable seedbed conditions (Battaglia et al. 2008, 2009).

Both increases and decreases in regeneration were observed 2-10 years post-treatment across all treatments and are attributed to site specific drivers and differences in biotic and abiotic factors associated with post-treatment seedling establishment. Ponderosa pine has episodic regeneration patterns throughout its range (Cooper 1960; Bailey and Covington 2002; Shepperd et al. 2006), and regeneration requirements include sufficient seed supply, light litter and forb cover, adequate soil moisture, and low seed and seedling predation by mammals and birds (Schubert 1974; White 1985). A general pattern of increased regeneration $11-20$ years following all treatments was observed. This is consistent with research that shows ponderosa pine seedling established 10 years post disturbance (Bonnet et al. 2005; Fajardo et al. 2007; Haire and McGarigal 2010). In studies where time since treatment was greater than 20 years, there was a trend in decreased regeneration compared to untreated stands, as some long-term studies reported that stands return to pre-treatment density and forest floor duff levels without subsequent maintenance treatments applied every 2-10 years (McDonald and Reynolds 1999; Ffolliott et al. 2009; Clyatt et al. 2017). This was due to survival of regeneration, ingrowth of small trees and accumulation of surface fuels. Some short-term ( $\leq 1$ year) decreases in regeneration may be due to mortality (upper end of regeneration height and dbh class), whereas later increases and decreases in the short-term (2-10 years) are reflective of the combination of recruitment, seedling mortality, and growth out of the seedling/sapling class into the overstory.

There were weak trends by type of treatment (thin-only, burn-only, and thin plus burn) and intensity of thinning. All treated stands demonstrated a change in regeneration density relative to the controls. In these studies, thin and thin plus burn treatments decreased ponderosa pine regeneration at one- and five-year intervals. Bailey and Covington (2002) observed 18-41 seedlings ha ${ }^{-1}$ in thinned areas and only 12 seedlings $\mathrm{ha}^{-1}$ on thin plus burn sites. However, a study in Montana showed that at ten years post-treatment, ponderosa pine had higher recruitment in the thin-only and thin plus burn treatments relative to controls, with the highest recruitment on thin plus burn sites (Fajardo et al. 2007). Thinning and thinning plus burning also increased the amount of regeneration and were effective at facilitating new cohorts of ponderosa pine in New Mexico (Thomas and Waring 2015). Reduction of the middle canopy layer by thinning plus burning in Washington State increased regeneration density relative to controls within a 10-year period (Harrod et al. 2009). Results from northern Arizona show that average seedling density ranged from 536 to 14,184 seedlings per $\mathrm{ha}^{-1}$ in harvested stands (Puhlick et al. 2012).

Several studies of ponderosa regeneration patterns after thinning in Montana (Fajardo et al. 2007), New Mexico (Thomas and Waring 2015), Colorado (Shepperd et al. 2006), and Arizona (Bailey and Covington 2002; Puhlick et al. 2012; Flathers et al. 2016) reported significantly greater regeneration densities in thinned stands versus unthinned stands (e.g., Fig. 2). Mechanical thinning and thinning plus prescribed fire increased seedling density over time but there was high variability among sites (Schwilk et al. 2009). Disturbances such as thinning and burning can lead to increased ponderosa pine regeneration by creating microsites for germination, or can reduce regeneration by causing direct injury or mortality (Bailey and Covington 2002). Regeneration can also be linked to variables such as stand density, light availability, soil moisture, disturbance, masting, and site productivity (Gray et al. 2005; Zald et al. 2008; Schwilk et al. 2009). Burn-only treatments created site conditions favorable to ponderosa pine seedling establishment two years following burning (Ffoliott and Guertin 1990). However, these treatments did not reduce tree density enough for high numbers of seedlings to persist in the long term ( $>20$ years). Without repeated prescribed fire, the forest floor returned to pre-fire conditions (Ffolliott and Guertin 1990).

Thinning and burning treatments have impacts on understory vegetation (Abella and Springer 2015), wildfire behavior (Fulé et al. 2012), wildlife diversity and abundance (Kalies et al. 2010), and change existing overstory spatial structures (Schwilk et al. 2009). Understory vegetation can reduce seedling mortality by protecting seedlings from wind and direct sunlight which may cause desiccation, but can also negatively affect regeneration via competition for soil moisture (Pearson 1942; Heidmann et al. 1982). Regeneration is influenced by spatial patterns and quality of overstory trees in a stand. Overstory tree basal area and density have negative relationships to pine seedling density and survival. Stands with high tree density and basal area have higher litter and duff depths which can limit seedling establishment (Graham 1990), and increase shade limiting seedling survival (Pearson 1950).

Several studies showed that the average ponderosa pine seedling density found in current forests was significantly higher than the historic density needed to maintain multiaged, heterogeneous stands. For example, Flathers et al. (2016) reported ponderosa pine seedling density ranging from 70 seedlings $\mathrm{ha}^{-1}$ in an un-thinned control to 4100 seedlings ha ${ }^{-1}$ at mid-level growing stock $\left(97\right.$ trees ha $\left.{ }^{-1}\right)$, and averaged 1713 seedlings $\mathrm{ha}^{-1}$ across all thinning treatments. In the Black Hills of South Dakota, ponderosa pine regeneration establishment often exceeded 1000 stems $\mathrm{ha}^{-1}$ (Shepperd and Battaglia 2002; Battaglia 2007). In the 


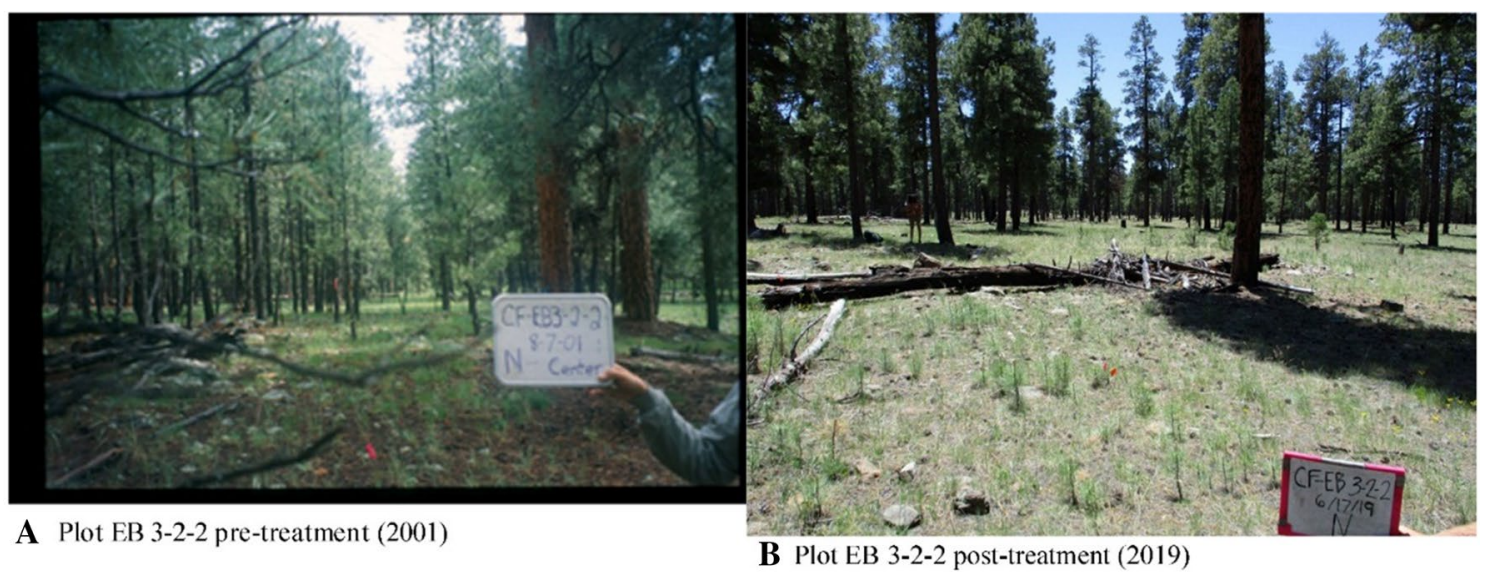

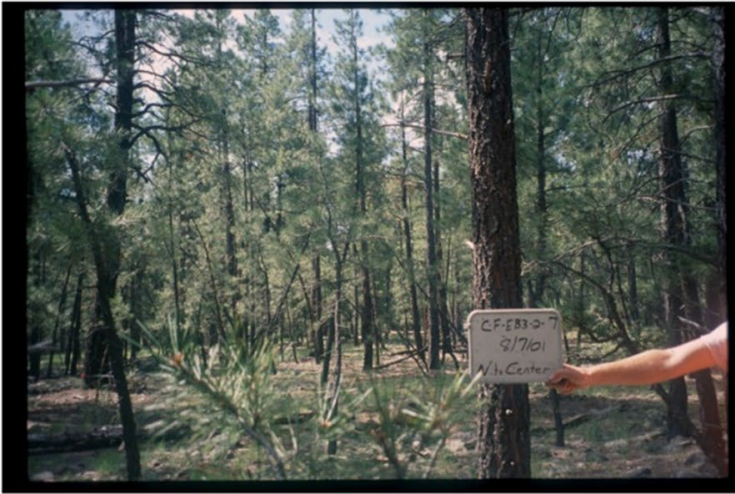

C Plot EB 3-2-7 pre-treatment (2001)

Fig. 2 Two ponderosa pine plots (EB 3-2-2 and EB 3-2-7) in northern Arizona at the Centennial Forest Long-term Ecological Assessment and Restoration Network (LEARN). Photos taken in 2019 show increased regeneration 15 years post thinning and 8 years post prescribed burning, and two plots pre-treatment (2001) and post-treat-

Colorado Front Range, regeneration density was 1243 stems $\mathrm{ha}^{-1}$ one year post treatment, more than twice the recommended stocking level (Briggs et al. 2017).

Restoring forest structure that is more resistant to crown fire will require maintaining ponderosa pine overstory at densities within the historical range of variability. Mast et al. (1999) found that successful regeneration as a result of just 3.6 trees $\mathrm{ha}^{-1}$ per decade was sufficient to produce multiaged, heterogeneous stands. Using prescribed fire to limit emerging regeneration and reduce accumulation of surface and ladder fuels can sustain fuel treatment goals (Sackett and Haase 1998; Brose and Wade 2002; Fulé et al. 2002; Raymond and Peterson; 2005; Hunter et al. 2007). Ponderosa pine regeneration often establishes within 10 years post treatment, and in many areas is prolific with over 1000 seedling per hectare (Battaglia et al 2008, 2009) (e.g., Fig. 2). In the absence of additional mechanical treatment or prescribed fire, these seedlings grow to saplings that develop into ladder fuels $10-20$ years post treatment and increase the potential

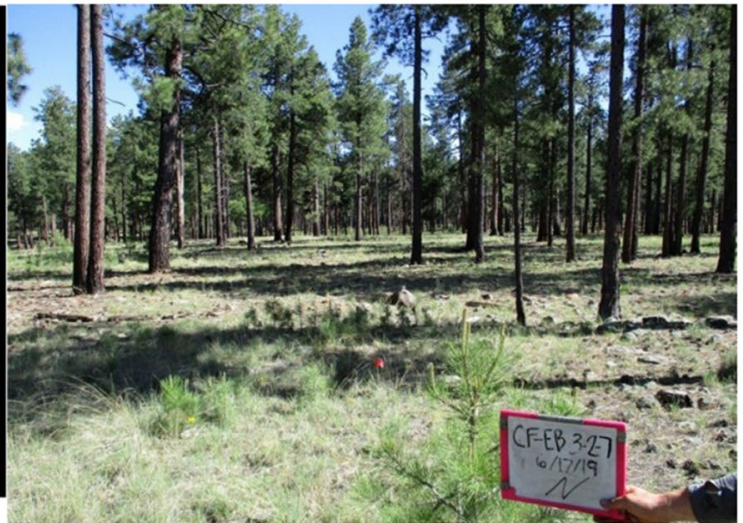

D Plot EB 3-2-7 post-treatment (2019)

ment (2019). Plots were mechanically thinned in 2004 and prescribed burned in 2011. Pre-treatment plots had zero and 100 seedling ha ${ }^{-1}$ respectively, and post-treatment seedlings increased to 7,400 and 10,600 seedlings $\mathrm{ha}^{-1}$ respectively by 2019

for crown fire if regeneration densities are not regulated by additional fuel treatments (Battaglia et al. 2009).

Disturbance can create ideal conditions for prolific regeneration in low-density stands of mature pine with frequent disturbance (Oliver and Ryker 1990; Shepperd and Battaglia 2002), and promote rapid growth of new or existing pine regeneration (Fajardo et al. 2007). Use of prescribed fire is necessary to control prolific regeneration and repeated use of prescribed fire is needed in treated stands to continue treatment effectiveness when open stands are desired. Repeated prescribed burning of surface fuels can enhance the seedbed, but repeated fire entry is shown to limit seedling survival during the first two decades following treatment (Bailey and Covington 2002). Dormant-season, low-severity fire can be used to control ponderosa pine regeneration density without killing the overstory (Battaglia et al. 2009). Retaining groups of overstory trees may also prevent regeneration from fully occupying all areas of the stand, and maintain a discontinuous, irregular forest structure (Youtz et al. 2007). 
Regeneration rates varied by site and are dependent on local precipitation and temperature, soil type, fire history, understory production, and other biotic and abiotic factors. Evaluating adequate regeneration establishment rates is complex and should be considered on a site-by-site basis where an understanding of the historical range of variability of forest structure and fire regimes is considered. Some ways to evaluate adequate pine regeneration rates in frequent-fire forests include using site-specific historical reference conditions (Fulé et al. 2002; Reynolds et al. 2013), silvicultural frameworks based on expectations of stand density, growth and mortality (Bailey and Covington 2002), or long-term monitoring and empirical data, and using simulation modeling (Puhlick et al. 2012). Historical stand density in ponderosa pine forests ranged from 10 to 125 trees ha $^{-1}$ in the southwest (Reynolds et al. 2013), from 11 to $96 \mathrm{ha}^{1}$ in the Sierra Nevada (Stephens et al. 2015), zero to 320 trees ha ${ }^{-1}$ in the Colorado Front Range (Brown et al. 2015), and averaged 97 trees ha ${ }^{-1}$ in lower montane forests in the Colorado and Wyoming Front Range (Battaglia et al. 2018). In western ponderosa pine forests, openings between trees were historically maintained by frequent ( $1-12$ years) low severity fire regimes (Covington and Moore 1994; Allen et al 2002; Taylor and Skinner 2003; Reynolds et al. 2013; Stephens et al. 2015). Fires were complex and effectively reduced competition between grasses and seedlings, prepared localized seedbeds for successful seedling establishment, and regulated seedling density and survival (Bailey and Covington 2002). The historical range of variability in tree density in western ponderosa pine forests leaves room for management decisions based on directives and priorities such as fire risk reduction, restoration, hydrology, fuels reduction, or habitat management for wildlife.

It was beyond the scope of this study to assess ponderosa regeneration rates with climate change (see Petrie et al. 2016); however, climate and wildfire will impact natural regeneration of ponderosa pine forests under predicted increased temperatures and drought conditions and changes in fire regimes. This suggests that climate change, including projected changes in precipitation, temperature, and soil moisture (Heidmann 2008; Petrie et al. 2016), may contribute to the factors that limit seedling establishment and growth in the future. Additionally, more rapid changes in forest ecosystems caused by drought, uncharacteristically severe wildfires, or insect outbreaks may lead to ecosystem changes to grass and shrub components, with reduced success in pine regeneration (Savage et al. 2013; Williams et al. 2013).

Long-term studies on natural pine regeneration rates in frequent-fire forests is needed. The episodic nature of masting, site productivity, soil moisture, drought, and seasonal precipitation can each control regeneration over time. In addition, successful seed germination and seedling survival are reliant on growing degree days, temperatures above freezing, canopy openings, low occurrence of surface fires, supply of seed trees, and soil type (Meagher 1950; Puhlick et al. 2012; Flathers et al. 2016; Petrie et al. 2017). Successful regeneration may require several years of favorable temperature and precipitation conditions, which are variable under a changing climate, leading to longer periods between successful seed years or even unsuitable conditions for regeneration on some sites (Flathers et al. 2016; Petrie et al. 2016, 2017; Dey 2019). Long-term studies that monitor regeneration response to treatments over long timeframes (e.g., Flathers et al. 2016) at a fine scale are needed to better understand regeneration dynamics and the long-term factors that influence rates of successful ingrowth into sapling and overstory lifeforms.

\section{Conclusions}

These studies suggest that frequent-fire forests with fuel reduction treatments, and/or restoration treatments, may need repeated maintenance to limit prolific regeneration, maintain resilient forest stands, and mitigate increased fire hazard over time. Fuel treatments in many ponderosa pine stands will lose their effectiveness within 10-20 years if regeneration densities are not controlled. Managers should consider maintaining the historical frequent-fire regime to limit overabundant pine regeneration and maintain tree densities at levels similar to the historical range of variability.

This review found that sites can display either increasing or decreasing amounts of regeneration in the short-term ( $<10$ years); therefore, it is recommended that management needs for regeneration be assessed minimally at 10 years post-treatment in frequent-fire pine dominated forests. Both increasing and decreasing trends in regeneration density were found in the short term ( $<10$ years), and increasing regeneration density trends $10-20$ years following treatment in frequent-fire pine forests in the western US. Mixed results were evident across multiple studies in the short-term ( $2-10$ years) following treatments due to the wide variability of treatments interacting with abiotic and climatic conditions in the study areas. Increases in the amount of regeneration were evident $11-20$ years post-treatment in thin-only, burn-only, and thin plus burn treatments, allowing a clearer picture of regeneration dynamics across treatments and time.

Overall, there was limited published data and empirical studies that specifically focused on regeneration responses to thinning and burning treatments in intact, frequent-fire forests. While the average ponderosa pine seedling density found in today's forests is substantially higher than recommended to maintain multi-aged, heterogeneous stands, there were few studies that documented the rates of mortality from 
the time of seedling emergence and through multiple fire cycles. Future studies on pine seedling survival on different soil types and with repeated fire are necessary to better quantify regeneration needs following treatments. In most cases, there is ample evidence that natural regeneration in ponderosa pine forests following mechanical thinning and/ or prescribed fire may be sufficient to initially meet management objectives and sustainable forestry guidelines.

Acknowledgements We would like to thank Dr. David Huffman for an early review of this manuscript. We thank the Ecological Restoration Institute for funding.

Open Access This article is licensed under a Creative Commons Attribution 4.0 International License, which permits use, sharing, adaptation, distribution and reproduction in any medium or format, as long as you give appropriate credit to the original author(s) and the source, provide a link to the Creative Commons licence, and indicate if changes were made. The images or other third party material in this article are included in the article's Creative Commons licence, unless indicated otherwise in a credit line to the material. If material is not included in the article's Creative Commons licence and your intended use is not permitted by statutory regulation or exceeds the permitted use, you will need to obtain permission directly from the copyright holder. To view a copy of this licence, visit http://creativecommons.org/licenses/by/4.0/.

\section{References}

Abatzoglou JT, Williams AP (2016) Impact of anthropogenic climate change on wildfire across western US forests. PNAS 113(42):11770-11775

Abella SR, Covington WW (2007) Forest-Floor treatments in Arizona Ponderosa Pine restoration ecosystems: no short-term effects on plant communities. Western North Am Naturalist 67(1):120-132

Abella SR, Springer JD (2015) Effects of tree cutting and fire on understory vegetation in mixed conifer forests. For Ecol Manage 335:281-299

Agee JK (1993) Fire Ecology of Pacific Northwest Forests. Island Press, Washington, DC

Agee JK, Skinner CN (2005) Basic principles of forest fuel reduction treatments. For Ecol Manage 211:83-96

Allen CD, Savage M, Falk DA, Suckling KF, Swetnam TW, Schulke T, Stacey PB, Morgan P, Hoffman M, Klingel JT (2002) Ecological restoration of southwestern ponderosa pine ecosystems: A broad perspective. Ecol Appl 12(5):1418-1433

Allen C, Macalady AK, Chenchouni AH, Bachelet D, McDowell N, Vennetie M, Kitzberger T, Rigling A, Breshears D, Hogg E, Gonzalez P, Fensham R, Zhang Z, Castro J, Demidova N, Lim J, Allard G, Running S, Semerci A, Cobb N (2010) A global overview of drought and heat-induced tree mortality reveals emerging climate change risks for forests. For Ecol Manage 259:660-684

Bailey JD, Covington WW (2002) Evaluating ponderosa pine regeneration rates following ecological restoration treatments in Northern Arizona, USA. For Ecol Manage 155(13):271-278

Battaglia MA, Smith FW, Shepperd WD (2008) Can prescribed fire be used to maintain fuel treatment effectiveness over time in Black Hills ponderosa pine forests? For Ecol Manage 256:2029-2038

Battaglia MA, Smith FW, Shepperd WD (2009) Predicting mortality of ponderosa pine regeneration after prescribed fire in the Black Hills, South Dakota, USA. Int J Wildland Fire 18:176-190
Battaglia MA, Gannon B, Brown PM, Fornwalt PJ, Cheng AS, Huckaby LS (2018) Changes in forest structure since 1860 in ponderosa pine dominated forests. For Ecol Manage 422:147-160

Battaglia MA (2007) Maintaining fuel treatments with prescribed fire in ponderosa pine (Pinus ponderosa) forests of the Black Hills, South Dakota. PhD dissertation, Colorado State University, Fort Collins, $\mathrm{CO}$

Bigelow SW, North MP, Salk CF (2011) Using light to predict fuelsreduction and group-selection effects on succession in Sierran mixed-conifer forest. Can J for Res 41(10):2051-2063

Bonnet VH, Schoettle AW, Shepperd WD (2005) Postfire environmental conditions influence the spatial pattern of regeneration for Pinus ponderosa. Can J for Res 35:37-47

Breshears DD, Cobb NS, Rich PM, Price KP, Allen CD, Balice RG, Romme WH, Kastens JH, Floyd ML, Belnap J, Anderson JJ, Myers OB, Meyer CW (2005) Regional vegetation die-off in response to global-change-type drought. PNAS 102:15144-15148

Briggs JS, Fornwalt PA, Feinstein JA (2017) Short-term ecological consequences of collaborative restoration treatments in ponderosa pine forests of Colorado. For Ecol Manage 395:69-80

Brose P, Wad D (2002) Potential fire behavior in pine flatwood forests following three different fuel reduction techniques. For Ecol Manage 163:71-84

Brown PM, Wu R (2005) Climate and disturbance forcing of episodic tree recruitment in a southwestern ponderosa pine landscape. Ecology 86(11):3030-3038

Brown PM, Battaglia MA, Fornwalt PJ, Gannon B, Huckaby LS, Julian C, Cheng AS (2015) Historical (1860) forest structure in ponderosa pine forests of the northern front range, Colorado. Can J for Res 45:1462-1473

Clyatt KA, Keyes CR, Hood SM (2017) Long-term effects of fuel treatments on aboveground biomass accumulation in Ponderosa pine forests of the northern rocky mountains. For Ecol Manage 400:587-599

Cooper CF (1960) Changes in vegetation, structure, and growth of southwest pine forests since white settlement. Ecol Monogr 30:129-164

Covington WW, Moore MM (1994) Southwestern ponderosa forest structure: changes since Euro-American settlement. J Forestry 92:39-47

Cueno KL (2011) Is Thin and Chip an Ecologically Viable Fuels Reduction Option? Initial Results in Black Hills Ponderosa Pine Forests. Thesis submitted to Colorado State University. Fort Collins, $\mathrm{CO}$

Dennison PE, Brewer SC, Arnold JD, Moritz MA (2014) Large wildfire trends in the western United States, 1984-2011. Geophys Res Lett 41(4):2928-2933

Dey CD, Knapp BO, Battaglia MA, Deal RL, Hart JL, O'Hara KL, Schweitzer CJ, Schuler TM (2019) Barriers to natural regeneration in temperate forests across the USA. New for 50:11-40

Fajardo A, Graham JM, Goodburn JM, Fiedler CE (2007) Ten-year responses of ponderosa pine growth, vigor, and recruitment to restoration treatments in the bitterroot mountains, Montana, USA. For Ecol Manage 243(1):50-60

Ffolliott PF, Stropki CL, Kauffman AT (2009) A 43-year evaluation of a prescribed fire: an arizona case study. Fire Ecology 5(1):79-84

Ffolliott PF, Baker Jr. MB (1977) Characteristics of Arizona ponderosa pine stands on sandstone soils. USDA Forest Service General Technical Report RM-44, 6

Ffolliott PF, Guertin DP (1990) Prescribed Fire in Arizona Ponderosa Pine Forests: A 24-Year Case Study. General Technical Report RM - Rocky Mountain Forest and Range Experiment Station, U.S. Department of Agriculture, Forest Service 191: 250-254 
Fiedler CE, Metlen K, Dodson EK (2010) Restoration treatment effects on stand structure, tree growth, and fire hazard in a ponderosa pine/douglas-fir forest in montana. For Sci 56(1):18-31

Flathers KN, Kolb TE, Bradford JB, Waring KM, Moser WK (2016) Long-term thinning alters ponderosa pine reproduction in Northern Arizona. For Ecol Manage 374:154-165

Francis D, Ex S, Hoffman C (2018) Stand composition and aspect are related to conifer regeneration densities following hazardous fuels treatments in Colorado, USA. For Ecol Manage 409:417-424

Fulé PZ, Covington WW, Moore MM, Heinlein TA, Waltz AEM (2002) Natural variability in forests of the Grand Canyon, USA. J Biogeogr 29:31-47

Fulé PZ, Roccaforte JP, Covington WW (2007) Posttreatment tree mortality after forest ecological restoration, Arizona, United States. Environ Manage 40:623-634

Fulé PZ, Crouse JE, Roccaforte JP, Kalies EL (2012) Do thinning and/ or burning treatments in western USA ponderosa or Jeffrey pinedominated forests help restore natural fire behavior? For Ecol Manage 269:68-81

Gaines EM, Kallander HR, Wagner JA (1958) Controlled burning in Southwestern Ponderosa Pine: results from the blue mountain plots. Fort Apache Indian Reservation J Forestry 56(5):323-327

Goodwin K (2004) Modeling natural regeneration of ponderosa pine on the Coconino National Forest in Arizona. Ph.D. dissertation, Northern Arizona University, Flagstaff, AZ, p 129

Graham RT, TB Jain (2005) Ponderosa Pine Ecosystems. USDA Forest Service General Technical Report PSW_GTR 198. https:// www.fs.fed.us/psw/publications/documents/psw_gtr198/psw_ gtr198_a.pdf

Graham RT(1990). Silvics of western white pine. In: Burns, R.M.; Honkala, B.H., technical coordinators. Silvics of North America. Vol 1. Conifers. Agricultural Handbook 654. Washington, DC: U.S. Department of Agriculture, pp 385-394

Gray AN, Zald HSJ, Kern RA, North M (2005) Stand conditions associated with tree regeneration in Sierran mixed-conifer forests. For Sci 51:198-210

Gutzler D, Robbins T (2011) Climate variability and projected change in the western United States: regional downscaling and drought statistics. Clim Dyn 37:835-849. https://doi.org/10.1007/ s00,382-010-0838-7

Hagmann RK, Franklin JF, Normin KN (2013) Historical structure and composition of ponderosa pine and mixed conifer forests in south-central Oregon. For Ecol Manage 304:492-504

Haire SL, McGarigal KM (2010) Effects of landscape patterns of fire severity on regenerating ponderosa pine forests (Pinus ponderosa) in New Mexico and Arizona, USA. Landscape Ecol 25:1055-1069

Hanberry B (2014) Compositional changes in selected forest ecosystems of the western United States. Appl Geogr 52:90-98

Harrod RJ, Petersen DW, Povak NA, Dodson EK (2009) Thinning and prescribed fire effects on overstory tree and snag structure in dry coniferous forests of the interior Pacific Northwest. For Ecol Manage 258:712-721

Haugo RD, Kellogg BS, Cansler CA, Kolden CA, Kemp KB, Robertson JC, Restaino CM (2019) The missing fire: quantifying human exclusion of wildfire in Pacific Northwest forests, USA. Ecosphere 10(4). https://doi.org/10.1002/ecs2.2702

Heidmann LJ, Johnson TN, Cole QW, Cullum G (1982) Establishing natural regeneration of ponderosa pine in central Arizona. J Forestry 80:77-79

Heidmann LJ (1988) Regeneration strategies for ponderosa pine. In: Baumgartner DM, Lotan JE (eds) Proceedings of conference on Ponderosa pine: the species and its management. Washington State University Press, pp 227-233
Heidmann LJ (2008) Forest regeneration research at Fort Valley. In: Olberding, SD, Moore, MMM (eds) Technical coordinators. 2008. Fort Valley Experimental Forest-A Century of Research 1908-2008. Proceedings RMRS-P-55. Fort Collins, CO: U.S. Department of Agriculture, Forest Service, Rocky Mountain Research Station. p 282

Hunter ME, Shepperd WD, Lentile LB, Lundquist JE, Andreu MG, Butler JL, Smith FW (2007) A comprehensive guide to fuels treatment practices for ponderosa pine in the Black Hills, Colorado Front Range, and Southwest. U.S. Forest Service General Technical Report, RMRS-GTR-198, Fort Collins, CO

IPCC (2013) Climate Change 2013: I. Cambridge University Press, London, The Physical Science Basis

IPCC (2018) Global Warming of $1.5^{\circ} \mathrm{C}$. Masson-Delmotte V, Zhai P, Pörtner H, Roberts D, Skea J, Shukla PR, Pirani A, MoufoumaOkia W, Péan C, Pidcock R, Connors S, Matthews JBR, Chen Y, Zhou X, Gomis MI, Lonnoy E, Maycock T, Tignor M, and Waterfield T (eds) An IPCC Special Report on the impacts of global warming of $1.5^{\circ} \mathrm{C}$ above pre-industrial levels and related global greenhouse gas emission pathways, in the context of strengthening the global response to the threat of climate change, sustainable development, and efforts to eradicate poverty

Jolly MW, Cochrane MA, Freeborn PH, Holden ZA, Brown TJ, Williamson GJ, Bowman DMJS (2015) Climate-induced variations in global wildfire danger from 1979-2013. Nat Commun 6L7537

Kalies EL, Chambers CL, Covington WW (2010) Wildlife responses to thinning and burning treatments in southwestern conifer forests: a meta-analysis. Forest Ecol Manag 259:333-342

Kalabokidis KD, Wakimoto RH (1992) Prescribed burning in unevenaged stand management of Ponderosa pine/douglas fir forests. J Environ Manage 34(3):221-235

Keeley JE, Zedler PE (1998) Evolution of life histories in Pinus. In: Richardson DM (ed) Ecology and Biogeography of Pinus. Cambridge University Press, Cambridge, UK, pp 219-250

Keyes CR, Maguire DA, Tappeiner JC (2007) Observed dynamics of ponderosa pine ( Pinus ponderosa var. ponderosa Dougl. ex Laws.) seedling recruitment in the Cascade Range, USA. New Forests 34(1):95-105

Korb JE, Fornwalt PJ, Stevens-Rumann CS (2019) What drives ponderosa pine regeneration following wildfire in the western United States? For Ecol Manage 454:117633

League K, Veblen T (2006) Climatic variability and episodic Pinus ponderosa establishment along the forest-grassland ecotones of Colorado. For Ecol Manage 228:98-107

Lortie CJ (2014) Formalized synthesis opportunities for ecology: systematic reviews and meta-analyses. Oikos 123:897-902

Mast JN, Fulé PZ, Moore MM, Covington WW, Waltz AEM (1999) Restoration of pre-settlement age structure of an Arizona Ponderosa pine forest. Ecol Appl 9(1):228-239

Meagher G (1950) Reproduction of ponderosa pine. J Forestry 48:188-191

Merschel AG, Beedlow PA, Shaw DC, Woodruff DR, Lee EH, Cline SP, Comeleo RL, Hagmann RK, Reilly MJ (2021) An ecological perspective on living with fire in ponderosa pine forests of Oregon and Washington: resistance, gone but not forgotten. Trees, Forests, and People. 4: 100074

Metlen KL, Fiedler CE (2006) Restoration Treatment effects on the understory of ponderosa pine/Douglas fir forests in western Montana, USA. For Ecol Manage 222:355-369

Moghaddas JJ, York RA, Stephens SL (2008) Initial response of conifer and california black oak seedlings following fuel reduction activities in a sierra nevada mixed conifer forest. For Ecol Manage 255(89):3141-3150

Moritz MA, Parisien M-A, Batllori E, Krawchuck MA, Van Dorn J, Ganz DJ, Hayhoe K (2012) Climate change and disruptions to global fire activity. Ecosphere 3(6): article 49 
Oliver WW, Ryker RA (1990) Pinus ponderosa Dougl. ex Laws. Ponderosa pine. In: Burns RM, Honkola RH (eds) Silvics of North America, 654. USDA Handbook, pp 173-180

Owen SM, Sieg CH, Sanchez Meador AJ, Fule PZ, Iniguez JM, Baggett LS, Fornwalt PJ, Battaglia MA (2017) Spatial patterns of ponderosa pine regeneration in high-severity burn patches. For Ecol Manage 405:134-149

Pearson GA (1942) Herbaceous vegetation a factor in natural regeneration of Ponderosa pine in the Southwest. Ecol Monogr 12:315-338

Pearson GA (1950) Management of ponderosa pine in the Southwest as developed by research and experimental practice. USDA Forest Service Agricultural Monograph 6, 218, Washington, DC

Petrie M, Wildeman AM, Bradford JB, Hubbard RM, Lauenroth WK (2016) A review of precipitation and temperature control on seedling emergence and establishment for ponderosa and lodgepole pine forest regeneration. For Ecol Manage 361:328-338

Petrie MD, Bradford JB, Hubbard RM, Laurenroth EK, Andrews C, Schlaepfer DR (2017) Climate change may restrict dryland forest regeneration in the 21st century. Ecology 98(6):1548-1559

Puhlick JJ, Laughlin DC, Moore MA (2012) Factors influencing ponderosa pine regeneration in the southwestern USA. For Ecol Manage 264:10-19

Pullin AS, Stewart GB (2006) Guidelines for systematic review in conservation and environmental management. Conserv Biol 20:1647-1656

Raymond CL, Peterson DL (2005) Fuel treatments alter the effects of wildfire in a mixed-evergreen forest, Oregon, USA. Can J for Res 35:2981-2995

Reynolds RT, Sánchez Meador AJ, Youtz JA, Nicolet T, Matonis MS, Jackson PL, DeLorenzo DJ, Graves AD (2013) Restoring composition and structure in Southwestern frequent-fire forests: A science-based framework for improving ecosystem resiliency. General Technical Report RMRSGTR-310. Fort Collins, CO: U.S. Department of Agriculture, Forest Service, Rocky Mountain Research Station. p 76

Roccaforte J, Fulé PZ, Covington WW (2010) Monitoring landscapescale ponderosa pine restoration treatment implementation and effectiveness. Restor Ecol 18(6):820-833

Roccaforte JP, Huffman DW, Fulé PZ, Covington WW, Stoddard MT, Crouse JE (2015) Forest structure and fuels dynamics following restoration treatments, white mountains, Arizona, USA. For Ecol Manage 337:174-185

Sackett S, Haase SE (1998) Two case histories for using prescribed fire to restore ponderosa pine ecosystems in northern Arizona. Pages 380-389 in Teresa L. Pruden and Leonard A. Brennan (Eds.). Fire in ecosystem management: shifting the paradigm from suppression to prescription. Tall Timbers Fire Ecology Conference Proceedings, No. 20. Tall Timbers Research Station, Tallahassee, FL

Sackett SS (1984) Observations on Natural Regeneration in Ponderosa Pine Following a Prescribed Fire in Arizona / Stephen S. Sackett. Research Note RM, 435. USDA Forest Service, Rocky Mountain Forest and Range Experiment Station

Savage M, Nystrom Mast J, Feddema JJ (2013) Double whammy: high-severity fire and drought in ponderosa pine forests of the Southwest. Can J For Res 43:570-583

Schoennagel T, Balch JK, Brenkert-Smith H, Dennison PE, Harvey BJ, Krawchuk MA, Mietkiewicz N, Morgan P, Moritz MA, Rasker R, Turner MG, Whitlock C (2017) Adapt to more wildfire in western North American forests as climate changes. PNAS 114(18):4582-4590

Schubert GH (1974) Silviculture of Ponderosa Pine: The Status-ofOur-Knowledge. Research Paper RM-123, US Department of Agriculture, Forest Service, Rocky Mountain Forest and Range Experiment Station, Fort Collins, CO
Schwilk DW, Keeley JE, Knapp EE, McIver J, Bailey JD, Fettig CJ, Fiedler CE, Harrod RJ, Moghaddas JJ, Outcalt KW, Skinner CN, Stephens SL, Waldrop TA, Yaussy DA, Youngblood A (2009) The national fire and fire surrogate study: effects of fuel reduction methods on forest vegetation structure and fuels. Ecol Appl 19:285-304

Seager R, Ting M, Held I, Kushnir Y, Lu J, Vecchi G, Huang H, Harnik N, Leetmaa A, Lau N, Li C, Velez J, Naik N (2007) Model projections of an imminent transition to a more arid climate in southwestern North America. Science 316:1181-1184

Shepperd WD, Edminster CB, Mata SA (2006) Long-term seedfall, establishment, survival, and growth of natural and planted ponderosa pine in the Colorado front range. West $\mathrm{J}$ Appl for 21:19-26

Shepperd WD, Battaglia MA (2002) Ecology, silviculture, and management of Black Hills ponderosa pine. USDA Forest Service, Rocky Mountain Research Station, General Technical Report, RMRS-GTR-97. Fort Collins, CO

Stein SJ, Kimberling DN (2003) Germination, establishment, and mortality of naturally seeded Southwestern Ponderosa pine. West J Appl for 18(2):109-114

Stephens SL, Skinner CN, Gill SJ (2003) Dendrochronology-based fire history of Jeffrey pine-mixed conifer forests in the Sierra San Pedro Martir, Mexico. Can J for Res 33:1090-1101

Stephens SL, Lydersen JM, Collins BM, Fry DL, Meyer MD (2015) Historical and current landscape-scale Ponderosa pine and mixed conifer forest structure in the Southern Sierra Nevada. Ecosphere 6(5):79

Stevens JT, Safford HD, Latimer AM (2014) Wildfire contingent effects of fuel treatments can promote ecological resilience in seasonally dry conifer forests. Can J for Res 44:843-854

Stoddard MT, Sanchez Meador AJ, Fulé PZ, Korb JE (2015) Fiveyear post-restoration conditions and simulated climate-change trajectories in a warm/dry mixed-conifer forest, Southwestern Colorado, USA. For Ecol Manage 356:253-261

Swetnam TW (1993) Fire history and climate change in giant sequoia groves. Science 262(5135):885-889

Taylor AH, Skinner CN (2003) Spatial patterns and controls on historical fire regimes and forest structure in the Klamath Mountains. Ecol Appl 13:704-719

Thomas Z, Waring K (2015) Enhancing resiliency and restoring ecological attributes in second-growth ponderosa pine stands in Northern New Mexico, USA. For Sci 61(1):93-104

Waltz AEM, Fulé PZ, Covington WW, Moore MM (2003) Diversity in ponderosa pine forest structure following ecological restoration treatments. For Sci 49(6):885-900

Westerling ALR (2016) Increasing western US forest wildfire activity: sensitivity to changes in the timing of spring. Philos Trans R Soc B 371:20150178

Westerling AL, Bryant BP, Preisler HK, Holmes TP, Hidalgo HG, Das T, Shrestha SR (2011) Climate change and growth scenarios for California wildfire. Clim Change 109:445-463

Westlind DJ, Kerns BK (2017) Long-term effects of burn season and frequency on ponderosa pine forest fuels and seedlings. Fire Ecology 13(3):42-61

White AS (1985) Pre-settlement regeneration patters in a southwestern ponderosa pine stand. Ecology 66:589-594

Williams AP, Allen CD, Macalady AK, Griffin D, Woodhouse CA, Meko DM, Swetnam TW, Rauscher SA, Seager R, GrissinoMayer HD, Dean JA, Cook ER, Gangodagamage C, Cai M, McDowell NG (2013) Temperature as a potent driver of regional forest drought stress and tree mortality. Nat Clim Change 3:292-297

Wolk B, Rocca MW (2009) Thinning and chipping small-diameter ponderosa pine changes understory plant communities on the Colorado Front Range. For Ecol Manage 257(1):85-95 
Youtz JA, Graham RT, Reynolds, RT, Simon J (2007) Implementing northern goshawk habitat management in southwestern forests: a template for restoring fire-adapted forest ecosystems in Integrated Restoration of Forested Ecosystems to Achieve Multi-Resource Benefits. In: Deal, R.L. (Ed.) Proc. Of the 2007

National Silviculture Workshop, USDA Forest Service General Technical Report PNWGTR-733, p 19
Zald HSJ, Gray AN, North M, Kern RA (2008) Initial tree regeneration responses to fire and thinning treatments in a Sierra Nevada mixed-conifer forest, USA. For Ecol Manage 256:168-179

Publisher's Note Springer Nature remains neutral with regard to jurisdictional claims in published maps and institutional affiliations. 